\title{
TOWARD A STRUCTURAL PERSPECTIVE ON \\ GENDER BIAS IN THE JUVENILE COURT
}

\author{
WILLIAM G. STAPLES \\ University of Southern California
}

A number of hypotheses about the effect of gender on the likelihood of incarceration in the juvenile court are tested. A purposive sample of 3911 delinquent (nonstatus) offending youths from 19 juristictions throughout the United States is analyzed employing the log-linear technique to control for the legal variables of severity of offense and prior record. The results indicate that females were less likely to be incarcerated than were males throughout the jurisdictions sampled. These and other findings lend support for a structural theory of gender bias in the juvenile court.

Research throughout the past decade has critically assessed the processes and procedures of the American juvenile justice system. One area of concern has been the extent to which the discretionary power of the court has led to gender bias. While the topic has generated considerable interest, some have argued that the literature assessing the extent to which extralegal factors (that is, produce bias in treatment. Moreover, differential treatment at earlier stages may influence the dispositional outcomes as a result of "bias amplification"(Farrell and Swigert, 1978). As Dannefer and Schutt (1982) point out, the court may actually compensate for bias that has occurred in earlier stages of processing. However, regardless of whether the actions of the court are compensatory or are biased in their own right, the result is unequal justice; and for those youths involved, such decisions may mean the difference between freedom and confinement. Hence, the focus here is on court action as a potential point of bias

AUTHOR'S NOTE: This article won First Prize in the Distinguished Student Paper Competition at the annual meeting of the Pacific Sociological Association, Seattle, April 11-14, 1984. Funding for the collection of data presented in this article was awarded to the Institute of Policy Analysis under 
race, class, sex, and so forth) affect decision making is plagued with methodological flaws and contradictory and inconclusive findings (see Dannefer and Schutt, 1982; Teilmann and Landry, 1981; Cohen and Kluegel, 1981). These criticisms have cited, among other factors, the absence of statistical controls on legal variables and the failure to consider interaction effects in attempts to identify bias.

Efforts to interpret existing findings are further complicated by two general theoretical frameworks that focus on different levels of analysis. These frameworks explain the existence of gender bias in terms of (1) the organization of the court and the immediate social environment, or (2) the social status or location of women in society.

While the focus of a number of articles on gender bias has been the female status offender (behavior for which only children can be arrested), the population considered here consists of youths who have been adjudicated delinquent for criminal offenses. Examining this population permits an assessment of the juvenile court's reaction to female criminality without the effect of what Chesney-Lind (1978:190) has called "sexual delinquency" (status offenses).

\section{ANALYZING COURT DISPOSITION AND INCARCERATION}

Clearly, the less formal stages of processing, such as arrest and intake, that occur prior to court disposition are more likely to

Grant Nos. 77-NI-99-0005 and 79-NJ-AX0009 from the Law Enforcement Assistance Administration, OJJDP/NIJJDP, Department of Justice, Washington D. C. Points of view or opinions stated here are those of the author and do not necessarily represent the official position or policies of the Department of Justice or the Institute of Policy Analysis. I gratefully acknowledge the efforts of Peter and Anne Schneider and the entire staff of the Institute of Policy Analysis for their collection of these data for the evaluation of the National Juvenile Restitution Initiative. I would also like to thank Daniel Glaser, Malcolm Klein, Katherine Teilmann Van Dusen, Robert Hodge, Clifford Staples, and Carol Waren for helpful suggestion on an earlier version of this article. 
in decision making, and incarceration as the most serious form of social sanction.'

\section{ORGANIZATIONAL AND SOCIAL STRUCTURAL DIMENSIONS}

It has become commonplace to view juvenile courts as individual systems of social control, replete with jurisdictional variation engendered by their own philosophies, goals, and procedures. Stapleton et al. (1982) have argued that such variation may explain the contradictory evidence of previous research on bias, since systematic assessment of organizational variation has not been undertaken. After creating a complex, static typology of metropolitan juvenile courts, the authors state that determinants of decision making should not be interpreted without knowledge of the specific jurisdictional context.

Using a similar organizational and environmental argument, Dannefer and Schutt (1982: 1130) state that the important question is "not whether there is bias in the juvenile justice system, but, rather, under what conditions is it more likely or less likely to occur," since, according to the authors, "It seems unlikely that bias is present or absent uniformly over a wide range of social settings" (1982:1114).

In contrast, those of the more macro, social structural perspective contend that the treatment of individuals by social control agencies is not dependent solely upon the behavior of individual offenders or the particular courts involved, but also on the social structural location of groups of individuals vis à vis other groups (see Black, 1976; Chambliss and Seidman, 1971; Quinney, 1970; Turk, 1969). Kruttschnitt (1980-1981:262) demonstrates this point in an empirical analysis of 1,034 adult female defendants. She found that "economic rank, respectability, and social integration all have a significant bearing ... on the sentences women offenders receive."

While it is not possible in this analysis to characterize the organizational diversity of the courts involved, it is possible to 
assess the degree to which jurisdictional variation affects overall pattern of treatment. If a pattern of bias is present throughout the sampled courts, this would indicate a stable, institutionalized pattern, possible reflecting a structural relationship. If however, the aggregate pattern is not consistent in each jurisdiction, one might conclude that organizational diversity was responsible. Both these dimensions are incorporated and tested in the following hypotheses.

\section{THEORETICAL PROPOSITIONS}

Hypothesis 1: Controlling for the legal variables of prior offense record and the severity of the current offense, females will be less likely to be incarcerated throughout all the courts sampled.

This structural hypothesis represents, in part, a notion articulated by Pollack (1950) that the treatment of young women by the juvenile court is basically chivalrous and benign. He argues that male agents of social control (that is, police, district attorneys, and judges) are reluctant to accuse and punish women. Further, it has been argued that such agents, as well as the community, perceive criminal acts committed by females as less serious than those committed by males (Datesman and Scarpitti, 1977). Barnes and Teeters (1952: 62) state that, "women are protected in a male dominated world"; and Reckless (1961: 37) claims that

female offenders have a much better chance than male offenders of not being reported, of not being arrested and of dropping out of the judicial process, that is of remaining uncommitted.

In an empirical analysis of six juvenile courts, Teilmann and Landry (1981) found that, throughout those courts, females were proportionately less likely to be incarcerated for committing a delinquent offense. Moreover, Cohen and Kluegel (1981) found in Memphis and Denver courts that males were more likely to be treated formally at intake for property offenses than were females. 
Further theoretical support for this hypothesis can be found in Black's (1976) theory of quantitative social control. According to him, the quantity of law applied to certain individuals or groups depends upon the quantity of nonlegal social control to which they are already subject. Thus, juveniles are subject to less legal treatment than are adults because of their subjection to other forms of authority (that is, parents, school personnel, and adults in general). Furthermore, it has been argued that female juveniles have been traditionally subject to greater quantities of such nonlegal authority than males (Chesney-Lind, 1978; Maccoby, 1966; Wietzman, 1975). Hence, we would expect that female offenders would be afforded less quantity of law than males by the juvenile court.

Hypothesis 2: The likelihood of incarceration for females and males will differ significantly within the legal categories of prior record and severity of current offense throughout all the courts sampled.

This structural hypothesis asserts that females will be treated differently than males for committing offenses that are considered violations of appropriate sex-role behavior. While this notion is behavioristic in the sense that the reaction of the court is based on the offenders' behaviors, it assumes that the reaction will be consistent throughout all the courts. Such consistency implies that the sex-role expectations are embedded in the nature of the social structural status of females.

One possible rationale for expecting variation in treatment is that the court sees females as "weaker, less responsible, and less dangerous than males"(Datesman and Scarpitti, 1977: 73). If this is the case, when there is participation in violent acts or where extensive damage is involved, the court may be more likely to severely punish a female. For example, Berstein et al. (1977) found that in adult courts in New York, women were more likely than men to be.convicted of serious charges. They state that women:

are prosecuted for the kinds of serious non-female typed offenses here examined ... they may be more severely responded to 
because they are violating expectations for appropriate sex-role behavior as well as appropriate law abiding behavior.

An alternative rationale for variation in treatment by offense may also be considered. The court may react more severely to females involved in minor delinquency in an effort to prevent more extensive involvement, while abandoning such protection when serious delinquency has already occurred. Support for this argument can be found in a number of articles (Terry, 1967; Anderson, 1976; Armstrong, 1977; Barton, 1976; Chesney-Lind, 1973, 1977, 1978; Conway and Bogdan, 1977; Datesman and Scarpitti, 1977) that claim that females are treated more severely than males for committing status offenses. Such behavior, while minor in nature, is said to be a violation of sexual norms, and the court's reaction a paternalistic response (Chesney-Lind, 1978). While no status offenders are included in this sample, the argument here is that "protective" dispositions are meted out to females who show evidence of evolving delinquent careers, and less punitive sanctions for those who appear out of the reach of protection.

Hypothesis 3: The likelihood of incarceration for females and males will differ significantly within the legal categories of prior record and severity of current offense and will not be consistent throughout all the courts sampled.

This hypothesis states that, while the court will react to offender behavior, such a reaction is inconsistent from one court to the next, which implies that the organizational context of particular courts accounts for such variation rather than any overall expectations about appropriate sex-role behavior.

Finally, some evidence indicates that differential treatment does not exist and hence none of these hypotheses will be supported. Teilmann and Landry (1981: 47) state that the literature assessing the degree of differential treatment against females in the system is "with few exceptions, seriously flawed and patently partisan." If this is the case, the evidence must be 
held in question. Consistent with this argument, Dannefer and Schutt (1982) found that sex had an insignificant impact on both police and court decision making in two New Jersey counties; and Carter (1979) found that gender failed to contribute to dispositional outcomes in a single southeastern court.

\section{THE DATA}

The data presented here were collected between 1978 and 1981 in 19 of the 85 courts participating in the National Juvenile Restitution Initiative, a federally funded juvenile justice program. ${ }^{2}$ These sites represent a wide range of regional and demographic characteristics throughout the United States. In order to ensure an adequate sample of incarcerated cases, these 19 courts were chosen because of their location in states where the rate of juvenile institutionalization is relatively high (U.S. Census, 1979; Krisberg et al., 1982).

A total of 3911 cases are analyzed..All the cases considered have been adjudicated delinquent. Table 1 lists the variables included in the present analysis, as well as their frequency distributions. For this study, offense type has been defined by a multidimensional scale containing offenses of increasing severity as defined by sections of the Uniform Crime Reports (UCR) and the amount of loss incurred by the victim. The amount of actual damage inflicted by the offender may be a better indication of danger to the community than the legal definition of the offense committed. The offenses were originally coded into UCR categories from behavioral descriptions.

\section{ANALYSIS}

The log-linear technique for analyzing qualitative variables was used to obtain a description of the relationship among prior offense record, seriousness of offense, gender, and court dis- 
TABLE 1

Variables in the Analysis

Variables

Categories

\section{Dependent :}

Court Disposition:

1. Incarcerated: commitment to

288 any secure facility, including detention centers.

2. Other: any court disposition other than incarceration as defined

Independent :

Offense type:

1. Minor: property or personal

offenses with loss/damage

of $\$ 10$ or less (except burg-

lary and arson)

2. Serious: burglaries, arsons, unarmed robberies and nonaggravated assaults with damages of $\$ 11$ to $\$ 250$ and any other property offense with loss/damage greater than $\$ 250$

3. Very Serious: burglaries, arsons, unarmed robberies and non-aggravated assults with loss/damage greater than $\$ 250$ and all UCR Part I personal crimes

Prior record:

1. No prior offense record

2. Prior offense record

Sex:

1. Male

position. This approach involves: first, estimation of the most general or "saturated" model from which significant effects are screened; second, selection of the best fitting model, that is, one whose expected frequencies most closely reproduce the observed frequencies, and is moreover, as parsimonious as possible; and third, assessment from this model of the specific effect of gender on disposition.

A multidimensional contingency table of sex (A) by prior offense record, (B) by seriousness of offense, (C) by court disposition, and (D) containing 24 cells, is presented in Table 2. 
TABLE 2

Sex by Prior Record by Seriousness of Current Offense by Court Disposition*

\begin{tabular}{|c|c|c|c|c|c|c|c|c|c|c|c|c|}
\hline \multirow[t]{3}{*}{ Disposition } & \multicolumn{4}{|c|}{ Minor } & \multicolumn{4}{|c|}{ Serious } & \multicolumn{4}{|c|}{ v. Sertous } \\
\hline & \multicolumn{2}{|c|}{ No priors } & \multicolumn{2}{|c|}{ Priors } & \multicolumn{2}{|c|}{ No Priors } & \multicolumn{2}{|c|}{ Priors } & \multicolumn{2}{|c|}{ No priors } & \multicolumn{2}{|c|}{ Priors } \\
\hline & $\underline{M}$ & $\underline{F}$ & $\underline{M}$ & $\underline{F}$ & $\underline{M}$ & $\underline{F}$ & $\underline{u}$ & $\underline{F}$ & $\underline{M}$ & $\mathbf{F}$ & M & $\mathbf{F}$ \\
\hline Other & $\begin{array}{c}81 \\
(154)\end{array}$ & $\begin{array}{c}90 \\
(35)\end{array}$ & $\begin{array}{c}75 \\
(197)\end{array}$ & $\begin{array}{c}84 \\
(31)\end{array}$ & $\begin{array}{c}79 \\
(684)\end{array}$ & $\begin{array}{c}82 \\
(102)\end{array}$ & $\begin{array}{c}68 \\
(888)\end{array}$ & $\begin{array}{c}71 \\
(82)\end{array}$ & $\begin{array}{c}74 \\
\text { (211) }\end{array}$ & $\begin{array}{c}79 \\
(22)\end{array}$ & $\begin{array}{l}60 \\
(378)\end{array}$ & $\begin{array}{c}76 \\
(19)\end{array}$ \\
\hline Incarcerated & $\begin{array}{c}19 \\
(36)\end{array}$ & $\begin{array}{r}10 \\
(4)\end{array}$ & $\begin{array}{c}25 \\
(66)\end{array}$ & $\begin{array}{l}16 \\
(6)\end{array}$ & $\begin{array}{c}21 \\
(181)\end{array}$ & $\begin{array}{c}18 \\
(23)\end{array}$ & $\begin{array}{c}32 \\
(423)\end{array}$ & $\begin{array}{c}29 \\
(33)\end{array}$ & $\begin{array}{r}26 \\
(74)\end{array}$ & $\begin{array}{r}21 \\
(6)\end{array}$ & $\begin{array}{l}40 \\
(250)\end{array}$ & $\begin{array}{r}24 \\
(6)\end{array}$ \\
\hline & $\begin{array}{c}100 \% \\
(190)\end{array}$ & $\begin{array}{l}100 \% \\
(39)\end{array}$ & $\begin{array}{l}100 \% \\
(263)\end{array}$ & $\begin{array}{l}100 \% \\
(37)\end{array}$ & $\begin{array}{l}100 \% \\
(865)\end{array}$ & $\begin{array}{l}100 \% \\
(125)\end{array}$ & $\begin{array}{c}100 \% \\
(1311)\end{array}$ & $\begin{array}{l}100 \% \\
(115)\end{array}$ & $\begin{array}{r}100 \% \\
(285)\end{array}$ & $\begin{array}{l}100 \% \\
(28)\end{array}$ & $\begin{array}{l}100 \% \\
(628)\end{array}$ & $\begin{array}{l}100 \% \\
(25)\end{array}$ \\
\hline
\end{tabular}

*Ns shown in parentheses. 


\section{TABLE 3}

Standardized Effect Parameters Involving Sex (A), Prior Record (B), Seiousness of Offense (C), and Court Disposition (D)

\begin{tabular}{|c|c|c|}
\hline & \multicolumn{2}{|c|}{ Disposition } \\
\hline $\begin{array}{l}\text { Sex-Disposition (AD) } \\
\qquad \begin{array}{l}\text { Male } \\
\text { Female }\end{array}\end{array}$ & $\begin{array}{r}-2.469 \star \\
2.469 *\end{array}$ & $\begin{array}{r}2.469^{\star} \\
-2.469^{\star}\end{array}$ \\
\hline $\begin{aligned} & \text { Priors-Disposition }(B D) \\
& \text { Nopriors } \\
& \text { Priors }\end{aligned}$ & $\begin{array}{r}2.710^{*} \\
-2.710^{*}\end{array}$ & $\begin{array}{r}-2.710^{*} \\
2.710^{*}\end{array}$ \\
\hline $\begin{array}{c}\text { Seriousness-Disposition (CD) } \\
\text { Minor } \\
\text { Serious } \\
\text { V.serious }\end{array}$ & $\begin{array}{r}2.641 \star \\
-1.119 \\
-1.913\end{array}$ & $\begin{aligned}-2.641 * \\
1.119 \\
1.913\end{aligned}$ \\
\hline $\begin{array}{lc}\text { Sex-Priors-Disposition (ABD) } \\
\text { Male } & \text { Nopriors } \\
\text { Female } & \\
\text { Male } & \text { Priors } \\
\text { Female } & \end{array}$ & $\begin{array}{r}0.315 \\
-0.315 \\
-0.315 \\
0.315\end{array}$ & $\begin{array}{r}-0.315 \\
0.315 \\
0.315 \\
-0.315\end{array}$ \\
\hline $\begin{array}{ll}\text { Sex-Seriousness-Disposition } \\
\text { Male } & \text { Minor } \\
\text { Female } & \\
\text { Male } & \text { Serious } \\
\text { Female } & \\
\text { Male } & \text { V.serious } \\
\text { Female } & \end{array}$ & $\begin{array}{r}-0.737 \\
0.737 \\
1.344 \\
-1.344 \\
-0.248 \\
0.248\end{array}$ & $\begin{array}{r}0.737 \\
-0.737 \\
-1.344 \\
1.344 \\
0.248 \\
-0.248\end{array}$ \\
\hline $\begin{array}{cl}\text { Priors-Seriousness } & \text { Diposition } \\
\text { Minor } & \text { Nopriors } \\
& \text { Priors } \\
\text { Serious } & \text { Nopriors } \\
& \text { Priors } \\
\text { V.serious } & \text { Nopriors } \\
& \text { Priors }\end{array}$ & $\begin{array}{r}-0.106 \\
0.106 \\
0.561 \\
-0.561 \\
-0.313 \\
0.313\end{array}$ & $\begin{array}{r}0.106 \\
-0.106 \\
-0.561 \\
0.561 \\
0.313 \\
-0.313\end{array}$ \\
\hline
\end{tabular}

$\star_{p}<.01$.

Table 3 presents the standardized effect parameters involving court disposition derived from fitting the saturated model. According to Goodman (1971), a standardized coefficient is equal to the effect parameter divided by its standard error and can be used to determine statistical significance in large samples.

The standarized effect parameters in Table 3 indicate that the main effects of sex (A), prior offense record (B), and the seriousness of current offense are all significant $(p<.01)$ and 


\section{TABLE 4}

Log-Linear Models for Four-Way Table of Court Disposition (D) by Sex (A) by Prior Record (B) by Seriousness of Offense (C)

\begin{tabular}{llccc}
\hline Model & $\begin{array}{c}\text { Marginals } \\
\text { Fit }\end{array}$ & d.f. & $\begin{array}{c}\text { Likelihood } \\
\text { Ratio }\end{array}$ & Prob \\
\hline 1 & $(A B C)(A D)(B D)(C D)$ & 7 & 3.28 & 0.8575 \\
2 & $(A B C)(A D)(B D)$ & 9 & 29.26 & 0.0006 \\
3 & $(A B C)(A D)(C D)$ & 8 & 59.74 & 0.0000 \\
4 & $(A B C)(B D)(C D)$ & 8 & 8.23 & 0.4116 \\
\hline
\end{tabular}

should be considered for inclusion in the final model. The higher order interactions presented, (ABD), (ACD), (BCD), as well as (ABC), not presented, are not significant. As a result, all two-way interactions are considered for inclusion in the final model.

Since it is appropriate to consider disposition as the dependent variable, the analysis is a "modified regression approach"(Goodman, 1972) or "logit"(Haberman, 1978), in which the odds of the expected cell frequencies of the dependent variable are specified. All models to be considered for the final model must contain a hierarchical term representing all the possible interactions among the independent variables (ABC). According to Goodman (1972: 38 ), the cell frequencies of this marginal table of independent variables are fixed by the research design, that is, the sample.

The selection of the final model is based on the fitting procedure shown in Table 4, in which a variety of models can be considered. The likelihood ratio statistic is used as the measure of fit.

The first model fit to the data specifies the interaction among the independent variables and all two-way interactions. This model fits the data quite well (likelihood-ratio 3.28, d.f. 7). Comparisons of models 2,3,4 with model 1 permit an assessment of the contributions of each main effect. Such comparison indicates that all these effects are significant and should be considered for inclusion in the final model. For instance, the specific contribution of sex and disposition (AD) is an increase in the likelihood ratio of 4.95 with 1 degree of freedom (the 
TABLE 5

Effect Parameters ( $\beta$ ) Involving the Dependent Variable Disposition (D)

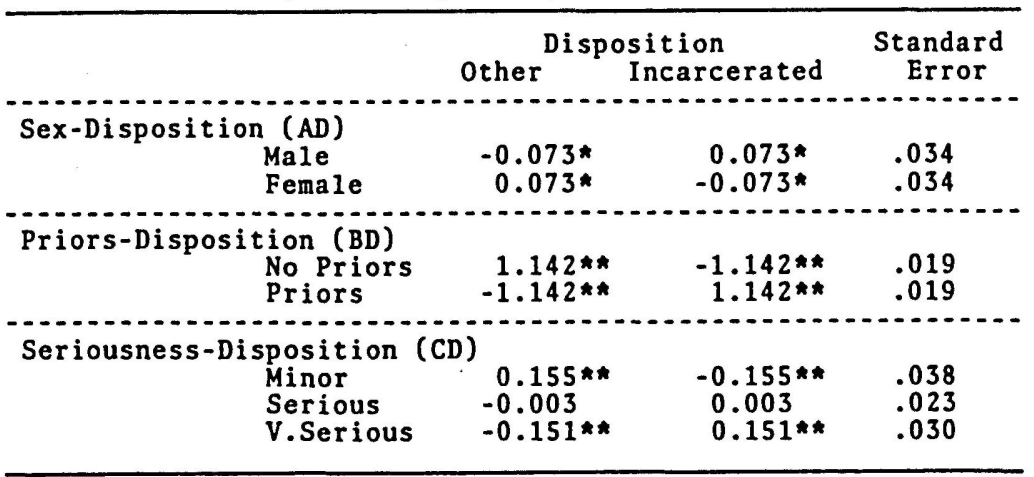

$*_{p}<.05$.

$\star \star p<.01$.

difference between models 1 and 4), which is significant at the p $<.05)$ level.

As a result of the model selection procedure, the first model containing all two-way interactions and the fixed (ABC) table was chosen as both the best fitting and most parsimonious model. While the model approaches "overfit," that is contains too many parameters due to the inclusion of $(A B C)$, it is the two-way effects that are of interest. These effects are both statistically and theoretically significant.

Having found a model that accurately represents the data, it is now possible to assess the specific effect of sex on incarceration (AD). The effect can be expressed in two ways (Goodman, 1972: 34). The first is the expected log-odds of the dependent variable in terms of beta parameters. The second is the multiplicative version. The estimated $\beta$ parameters and their standard errors are arrayed in Table 5.

As the beta effect parameters in Table 5 indicate that the effect of sex on disposition is significant $(p<.05)$. While it is clear that the legal variables of prior offense record (DB) and the seriousness of the current offense (DC) strongly affect the disposition outcome $(p<.01)$, gender is also a significant influence. 
TABLE 6

Multiplicative $(\gamma)$ Parameters Involving Dependent Variable Disposition (D)

\begin{tabular}{|c|c|c|}
\hline & Other & Incarcerated \\
\hline Sex-Disposition (AD) $\begin{array}{l}\text { Male } \\
\\
\text { Female }\end{array}$ & $\begin{array}{l}0.929 \\
1.076\end{array}$ & $\begin{array}{l}1.076 \\
0.929\end{array}$ \\
\hline $\begin{array}{c}\text { Priors-Disposition (BD) } \\
\text { No Priors } \\
\text { Priors }\end{array}$ & $\begin{array}{l}1.153 \\
0.868\end{array}$ & $\begin{array}{l}0.868 \\
1.153\end{array}$ \\
\hline $\begin{aligned} \text { Seriousness-Disposition (CD) } \\
\text { Minor } \\
\text { Serious } \\
\text { V.Serious }\end{aligned}$ & $\begin{array}{l}1.167 \\
0.997 \\
0.860\end{array}$ & $\begin{array}{l}0.857 \\
1.003 \\
1.163\end{array}$ \\
\hline
\end{tabular}

Because it lends itself to appealing interpretations in terms of odds and odds ratios, the multiplicative version is also presented. These effect parameters, $\gamma$ (gamma) equal to the exponential function of $\beta$ (Goodman, 1972). In order to interpret the $\gamma$ effect parameter involving sex and disposition presented in Table 6, Long's (1982) approach for assessing estimability and interpretation is used.

Accordingly, the main effect (AD) can be estimated since no higher order term containing this effect is present. The total effect of sex on disposition is estimated by the function:

$$
\frac{\gamma_{12}^{(\mathrm{AD})} / \gamma_{11}^{(\mathrm{AD})}}{\gamma_{21}^{(\mathrm{AD})} / \gamma_{22}^{(\mathrm{AD})}} \text { OR } \frac{\frac{.929}{1.076}=.863}{\frac{1.076}{.929}=1.158} \frac{.863}{1.158}=.745
$$

Hence, we can state that, for males, the average odds of being incarcerated for any category of prior record or current offense is multiplied by a factor of 1.16 times. For females, on the other hand, the odds of being incarcerated, controlling for the legal variables, is 0.86 times the average odds. Thus, the female odds of incarceration are .745 of the male odds. 
TABLE 7

Regression of Sex, Prior Record, and Seriousness on Disposition With and Without Site Dummy Variables

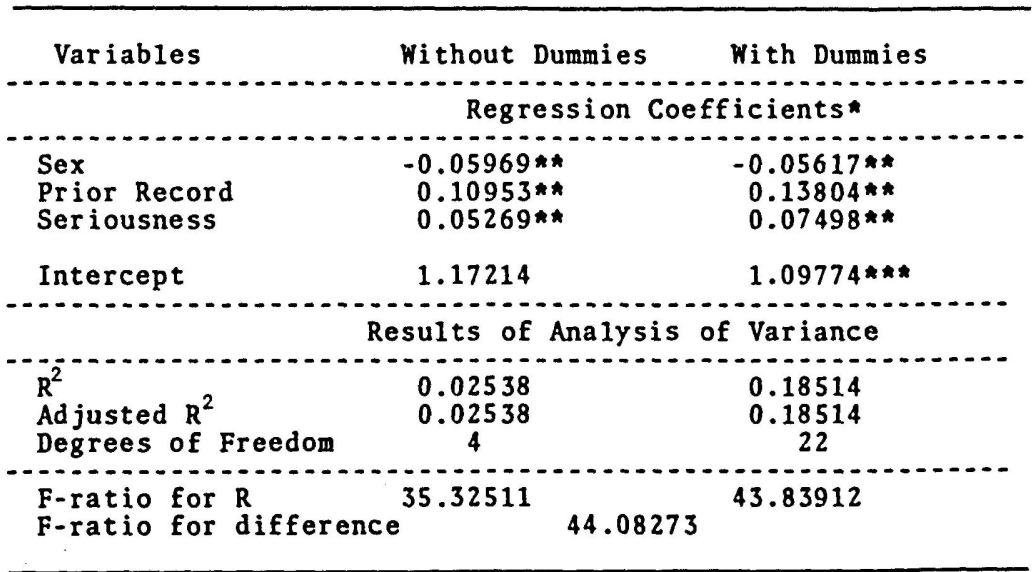

* Raw score form.

* Coefficient is more than twice its standard error.

*** Rather than report the regression coefficlents for all 18 sites, this term can be represented by the equation:

$$
a_{y p d}^{\prime}=a+\Sigma_{b_{j}} D_{k}
$$

where aypd equals the standard intercept term, $b_{j}$ equals the sum of the dummy site coefficlents, and $D_{k}$ the proportion of the sample in each site.

As a final step in this analysis, the effect of organizational variation is estimated. Table 7 presents the results of two regression equations. ${ }^{3}$ The first is a regression of sex, prior record, and seriousness of offense on disposition (all defined as in the previous analysis). The second contains the same variables with the addition of 18 dummy variables representing the various jurisdictions. (One site was excluded to avoid linear dependency).

The results of this regression analysis indicate that the relationship among the parameters identified by the log-linear model, (DA)(DB)(DC), is generalizable throughout these jurisdictions. Comparison of the regression coefficients from each equation indicates that the addition of site dummy variables does not significantly alter their magnitude or direction. This is not to say that site has no effect, but rather that, despite jurisdictional and organizational variation, the model does reflect the dispositional procedures of this sample of courts. 
In part, the results may be accounted for by the purposive sampling technique. That is, selecting courts based on their use of incarceration may reduce organizational variation by producing a sample of "punitive" courts. Yet, those arguing from the organizational perspective (Stapleton et al., 1982; Dannefer and Schutt, 1982) contend that the complexity of the juvenile court defies such simplistic typologies. Indeed, given the variety of jurisdictions sampled, it is unlikely that the results are an artifact of sampling.

\section{DISCUSSION}

This analysis has permitted the consideration of three theoretical hypotheses dealing with the possibility of gender bias in the juvenile court. The results support the first hypothesis. Throughout these courts, females were less likely to be incarcerated than males. While hypotheses 2 and 3 suggested differences in the likelihood of incarceration, such treatment should have varied by the type of offense or by the number of prior offenses throughout these courts (2) or the pattern would have significantly varied from court to court (3). This was not the case. Neither the interactions of sex and priors with disposition (ABD) nor with offense type (ACD) significantly contributed to the final model.

The results reported here provide support for a social structural perspective on gender bias. What has been interpreted as chivalrous treatment in the past is, from a structural perspective, a result of the differing social status of male and female juveniles. Black's (1976) quantity of law and social control theory addresses this issue. If females are subject to greater amounts of nonlegal social control than are males, then we would expect that the court would apply a smaller quantity of legal control to females, as was found here. The exception would be when females are referred to the court by parents or other representatives of nonlegal authority who insist that the young person is out of their control and that it is up to the court to correct her misbehavior. 
The empirical evidence suggests that this is the case. Ketcham (1978) contends that $72 \%$ of all status offenders are referred by adults. Teilmann and Landry (1981: 74-75) argue that parental referrals may account for the overrepresentation of females in the system for status offenses; and in their own analysis they found no systematic gender bias against female status offenders. Yet, as mentioned above, they found in the same study that, throughout all the sites examined, females are proportionately less likely to be incarcerated for committing a delinquent offense. Moreover, Cohen and Klugel (1981) found that males were more likely to be treated formally at intake for property offenses than were females, while again there was no difference in treatment for status offenses.

Interpreting the existing evidence on gender bias from a social structural perspective yields a fairly consistent pattern of differential treatment. The pattern indicates that the juvenile court, by applying less severe legal sanctions, may be more willing to rely on nonlegal forms of social control to correct or guide the future behavior of young women as compared to young men. This is the case for police referred criminal offenses such as those examined here. However, when nonlegal authority is either unwilling or unable to control the behavior of young people (as is the case with most referred status offenders), the court may be more willing to treat females in the same manner as males.

\section{CONCLUSION}

The results of an analysis of dispositional outcomes of 19 juvenile courts to assess the effect of gender on the likelihood of incarceration support the hypothesis that females are less likely to be incarcerated for committing delinquent offenses than their male counterparts; and the results were generalizable throughout this sample of courts. This and other empirical evidence cited suggest that the courts' treatment of females may be guided, in part, by consideration of the extent to which these juveniles are subject to nonlegal social control, a function of the social status of females relative to males. 
By analyzing a relatively large number of courts and by assessing the impact of jurisdictional variation across those courts, this analysis has considered both social structural or organizational explanations of differential treatment. While the study is limited by its purposive rather than random sample, it represents a preliminary attempt to address the question of gender bias throughout a relatively large number of jurisdictions and to clarify seemingly contradictory evidence regarding gender bias in juvenile courts.

\section{NOTES}

1. While some evidence suggests that the offender may not perceive incarceration as a severe sanction, it is the most serious sanction available from the perspective of social control agents.

2. For a more detailed description of the National Juvenile Restitution Initiative see Schneider et al., 1982.

3. A shift in analytical models (a "modified" regression to ordinary least squares) is necessary at this point, given the number of courts-sampled. This technique may be considered robust, since the distribution of cases on the dependent variable is not adversely skewed (that is, not less than $25 \%$ in the lower category; see Bohrnstedt and Carter, 1971).

\section{REFERENCES}

Anderson, E.

1976 "The 'chivalrous' treatment of female offenders in the arms of the criminal justice system: a review of the literature." Social Problems 23: 350-357.

Armstrong, G.

1977 "Females under the law-'protected' but unequal." Crime and Delinquency 23: $109-120$.

Barnes, H. E. and N. K. Teeters

1959 New Horizons in Criminology. Englewood Cliffs, NJ: Prentice Hall.

Barton, W. H.

1976 "Discretionary decision-making in juvenile justice." Crime and Delinquency 22: $470-480$.

Berstein, I., E. Kick, E. Leong, and B. Schultz

1977 "Charge reduction: an intermediary step in the process of labelling criminals." Social Forces 56: 362-384. 
Black, D. J.

1976 The Behavior of Law. New York: Academic Press.

Bohrnstedt, G. and T. Carter

1971 "Robustness in regression analysis," in H. Costner (ed.) Socilological Methodology. San Francisco: Jossey-Bass.

Carter, $T$.

1979 "Juvenile court dispositions: a comparison of status and nonstatus offenders." Criminology 17: 341-360.

Chambliss, W., and R. Seidman

1971 Law Order and Power. Reading, MA: Addison-Wesley.

Cohen, L. and J. Kluegel

1981 “Selecting delinquents for adjudication." Crime and Delinquency 16: 143-163. Chesney-Lind, $M$.

1973 "Judicial enforcement of the female sex role: the family court and the delinquent female offender." Issues in criminology 8: 51-69.

1977 "Judicial paternalism and the female status offender": training women to know their place." Crime and Delinquency 23: 121-130.

1978 "Young women in the arms of the law," and "Chivalry reexamined: women and the criminal justice system," pp. 171-219 in L. B. Gowker (ed.) Women, Crime and the Criminal Justice System. Lexington, MA: D.C. Heath.

Conway, A. and C. Bogdan

1977 "Sexual delinquency: the persistence of a double standard." Crime and Delinquency 23: 131-135. .

Dannefer, D. and R. Schutt

1982 "Race and juvenile justice processing in court and police agencies." Amer. J. of Sociology 87: 1113-1132.

Datesman, S. K. and F. R. Scarpitti

1977 "Unequal protection for males and females in the juvenile court," in T.N. Ferdinand (ed.) Little Brother Grows Up. Beverly Hills, CA: Sage Publications.

Ferrell, R. and V. L. Swigert

1978 "Prior offense as a self-fulfilling prophecy." Law and Society Rev. 12: 437-453.

Goodman, L.

1972 "A modified multiple regression approach to the analysis of dichotomous variables." Amer. Soc. Rev. 37: 28-46.

Haberman, S. J.

1978 Analysis of Qualitative Data. New York: Academic Press.

Ketcham, O. W.

1978 "Why jurisdiction over status offenders should be eliminated from juvenile court," pp 33-50 in R. Allison (ed.) Status Offenders and the Juvenile Justice System. Hackensack, NJ: National council on Crime and Delinquency.

Krisberg, B., I. Schwartz, and P. Litsky

1982 "Youth in confinement: justice by geography," Unpublished paper, National Council on Crime and Delinquency, San Francisco, CA.

Kruttschnitt, C.

1980 "Social status and the sentences of female offenders." Law and Society Rev. 15.

Long, J. S.

1982 "Estimable functions in log-linear models," Unpublished paper presented at the American Sociological Association Meetings, San Francisco, CA. 
Maccoby, E. (ed.)

1966 The Development of Sex Differences. California: Stanford Univ. Press.

Pollak, 0.

1950 The Criminality of Women. Philadelphia: Univ. of Pennsylvania Press.

Quinney, R.

1970 The Social Reality of Crime. Boston: Little, Brown.

Schneider, P., W. Griffith, and A. Schneider

1982 "Juvenile restitution as a sole sanction or condition of probation: an empirical analysis." Crime and Delinquency 19.

Stapleton, V., D. P. Aday, and J. Ito

1982 "An empirical typology of American metropolitan juvenile courts." Amer. J. of Soc. 88: 549-564.

Reckless, W.

1961 The Crime Problem. New York: Appleton-Crofts.

Teilmann, K. and P. Landry

1981 "Gender bias in juvenile justice." Crime and Delinquency 1: 47-80.

Terry, R. M.

1967 "Discrimination in handling of juvenile offenders by social-control agencies." Crime and Delinquency 4: 218-230.

Turk, A.

1969 Criminality and the Legal Order. Chicago: Rand-McNally.

U.S. Department of Justice

1979 Bureau of Justice Statistics, Children in Custody: A Report on Juvenile Detention and Correctional Facility Census of 1975. Washington, DC: U.S. Government Printing Office.

Weitzman, L. J.

1975 "Sex role socialization," in Women: A Feminist Perspective. Palto Alto: Mayfield.

William G. Staples is a Ph.D. candidate in the Department of Sociology and a research assistant at the Social Science Research Institute of the University of Southern California. He has been a research assistant at the Institute of Policy Analysis in Eugene Oregon and is currently preparing a monography on the changing nature of contemporary social control institutions. 